\title{
Pengaruh Partisipasi Penyusunan Anggaran, Budaya Organisasi Dan Evaluasi Anggaran Terhadap Kinerja Manajerial Dengan Gaya Kepemimpinan Sebagai Variabel Moderating: Studi Kasus Pada Bank BTN Kantor Bandar Lampung
}

\author{
Venna Monica Aginta Ginting, Erlina, H. B. Tarmizi \\ Universitas Sumatera Utara, Indonesia \\ Email corresponding authors: vennamonicaagintaginting@gmail.com
}

\begin{abstract}
ABSTRAK
Penelitian ini bertujuan untuk mengetahui dan menganalisis apakah Pengaruh Partisipasi Penyusunan Anggaran, Budaya Organisasi dan Evaluasi Anggaran terhadap Kinerja Manajerial. Penelitian ini juga akan menguji variabel Gaya Kepemimpinan yang dijadikan sebagai variabel pemoderasi dalam model penelitian. Populasi dalam penelitian ini adalah pada Bank BTN Kantor Cabang Bandar Lampung. Metode penelitian dalam tesis ini adalah analisis statistik deskriptif, uji validitas, uji hipotesis dan uji moderasi. Variabel Independen pada penelitian ini adalah Pengaruh Partisipasi Penyusunan Anggaran, Budaya Organisasi dan Evaluasi Anggaran sedangkan Variabel Dependennya adalah kinerja manjerial. Jumlah populasi penelitian ini terdiri dari 50 karyawan dengan menggunakan sampel jenuh diperoleh 50 orang sebagai sampel. Jenis data yang dipakai adalah data primer. Metode analisis yang digunakan adalah analisis regresi berganda. Hasil penelitian ini menunjukkan bahwa Pengaruh Partisipasi Penyusunan Anggaran, Budaya Organisasi dan Evaluasi Anggaran berpengaruh positif dan signifikan terhadap kinerja manajerial. Hasil penelitian ini juga menunjukkan bahwa Gaya Kepemimpinan tidak mampu memoderasi Pengaruh Partisipasi Penyusunan Anggaran, Budaya Organisasi dan Evaluasi Anggaran terhadap Kinerja Manajerial.
\end{abstract}

Kata Kunci: Partisipasi Penyusunan Anggaran, Budaya Organisasi, Evaluasi Anggaran, Kinerja Manajerial, Gaya kepemimpinan

\section{PENDAHULUAN}

Kinerja Manajerial adalah kinerja individu dalam kegiatan-kegiatan manajerial. Kinerja manajerial yang efektif dalam melaksanakan fungsi-fungsi manajemen yang meliputi: kinerja perencanaan (Planning), kinerja investigasi (Investigating), kinerja pengkoordinasian (Coordinating), kinerja evaluasi (Evaluation), kinerja pengawasan (Monitoring), kinerja pengaturan staf (Staffing), kinerja negosiasi (Negotiating), kinerja perwakilan (Representating)" Kurnianingsih (2003).

Kinerja Manajerial Bank BTN Kantor Cabang Bandar Lampung memiliki permasalahan dalam bidang dana dimana tiga tahun terakhir target tidak sesuai dengan realisasi yang ada, dengan keterangan Ditahun 2016 target 521.611, realisasi 440.682. Ditahun 2017 target 629.971, realisasi 478.150. Ditahun 2018 target 642.308 realisasi 514.622 (dalam jutaan). Kinerja manajerial Pada Bank BTN Kantor Bandar Lampung diatas, dapat dilihat ada kinerja dana yang tidak tercapai, mengakibatkan persaingan antar bank dalam merebut pasar dana masyarakat menjadi semakin tinggi. Untuk menghadapi persaingan tersebut setiap bank menggunakan berbagai teknik pemasaran yang berbeda baik dengan memanfaatkan jaringan distribusi yang dimiliki, kualitas jasa dan pelayanan dan berbagai pendekatan lainnya. 


\section{KAJIAN PUSTAKA}

\section{Teori Sifat Kepribadian (Trait Theory)}

Teori Sifat Kepribadian atau Trait Theory ini mempercayai bahwa orang yang dilahirkan atau dilatih dengan kepribadian tertentu akan menjadikan mereka unggul dalam peran kepemimpinan. Artinya, kualitas kepribadian tertentu seperti keberanian, kecerdasan, pengetahuan, kecakapan, daya tanggap, imajinasi, fisik, kreativitas, rasa tanggung jawab, disiplin dan nila-nilainya lainnya dapat membuat seseorang menjadi pemimpin yang baik. Teori kepemimpinan ini berfokus pada analisis karakteristik mental, fisik dan sosial untuk mendapatkan lebih banyak pemahaman tentang karakteristik dan kombinasi karakteristik yang umum diantara para pemimpin. Keberhasilan seseorang dalam kepemimpinan sangat tergantung pada sifat kepribadiannya dan bukan saja bersumber dari bakat namun juga berasal dari pengalaman dan hasil belajarnya.

\section{Telaah Literatur}

Kinerja manajerial perusahaan dapat menggunakan rasio keuangan. Rasio keuangan menunjukkan perubahan dalam kondisi keuangan perusahaan serta potensi perusahaan dalam mengelola kekayaan perusahaan dalam meningkatkan nilai perusahaan (Tjandrakirana dan Monika). Nilai perusahaan dapat menunjukkan kepada para investor tentang prestasi perusahaan dalam mengelola sumber daya.

Variabel kinerja manajerial diukur dengan menggunakan instrument self rating yang dikembangkan oleh Kurnianingsih dimana setiap responden diminta untuk mengukur kinerja sendiri kedelapan dimensi, yaitu perencanaan, investigasi, pengkoordinasian, evaluasi, pengawasan, pemilihan staf, negosiasi, dan perwakilan, serta suatu dimensi pengukuran kinerja seseorang kepala bagian, kepala urusan dan asisten urusan secara keseluruhan.

Partisipasi dalam penyusunan anggaran adalah diperlukan kerjasama antara seluruh tingkatan organisasi. Dimana Manajer puncak biasanya mempunyai perspektif yang lebih luas atas perusahaan secara keseluruhan yang sangat vital dalam pembuatan anggaran secara umum. Garrison dan Noreen (2000) "setiap tingkatan tanggung jawab dalam suatu organisasi harus memberikan masukan terbaik sesuai dengan bidangnya dalam suatu sistem kerjasama penyusunan anggaran”.

Budaya organisasi adalah sebuah sistem makna bersama yang dianut oleh para anggota yang membedakan suatu organisasi dari organisasi-organisasi lainnya. Sistem makna bersama ini adalah sekumpulan karakteristik kunci yang dijunjung tinggi oleh organisasi. Sebuah karakteristik yang dijunjung tinggi oleh organisasi dan menjadi panutan organisasi sebagai pembeda antara satu organisasi dengan organisasi yang lain. Atau budaya organisasi juga diartikan sebagai nilai-nilai dan norma perilaku yang diterima dan dipahami secara bersama oleh anggota organisasi sebagai dasar dalam aturan perilaku yang terdapat dalam organisasi tersebut.

Evaluasi anggaran diperlukan dalam setiap pelaksanaan anggaran, evaluasi ini untuk mengetahui sejauh mana keberhasilan dalam pelaksanaannya, yaitu menilai kembali apakah anggaran yang dilakukan sudah sesuai dengan yang ditetapkan dalam mencapai tujuannya. Salah satu cara untuk mengevaluasi kinerja adalah dengan program penganggaran, karena dengan anggaran dapat menentukan tujuan dan sasaran Garrison dan Noreen (2000). Uzer (2003), mengatakan bahwa Evaluasi adalah suatu proses yang ditempuh seseorang untuk memperoleh informasi yang berguna untuk menentukan mana dari dua hal atau lebih yang merupakan alternatif yang diinginkan, karena penentuan atau keputusan semacam ini tidak diambil secara acak, maka alternatif-alternatif itu harus diberi nilai relatif, karenanya 
pemberian nilai itu harus memerlukan pertimbangan yang rasional berdasarkan informasi untuk proses pengambilan keputusan.

Gaya kepemimpinan didefinisikan sebagai suatu norma perilaku yang digunakan oleh seseorang pada saat orang tersebut mencoba untuk mempengaruhi perilaku orang lain seperti yang dia lihat. Menurut Thoha (2006) kepemimpinan didefinisikan sebagai suatu kegiatan yang ditunjukan untuk mempengaruhi perilaku orang lain atau seni untuk mempengaruhi perilaku manusia

baik perorangan maupun secara kelompok. Menurut Terry (1990) ada beberapa tipe gaya kepemimpinan yang terdiri dari:

1. Tipe kepemimpinan otokratis (Autocratis)

2. Tipe kepemimpinan demokratis (democratis)

3. Tipe kepemimpinan bebas (laissez faire).

Dalam tipe ini pemimpin hanya sedikit/sama sekali tidak memberikan pengarahan pada bawahan, ia lebih bersifat pasif dan seolah-olah tidak mampu memberikan pengaruh terhadap bawahannya.

\section{Kerangka Penelitian}

Kerangka konseptual yang dikembangkan oleh peneliti berdasarkan latar belakang, rumusan masalah, tujuan penelitian dan landasan teori yang akan di uji, dapat dilihat pada gambar berikut:

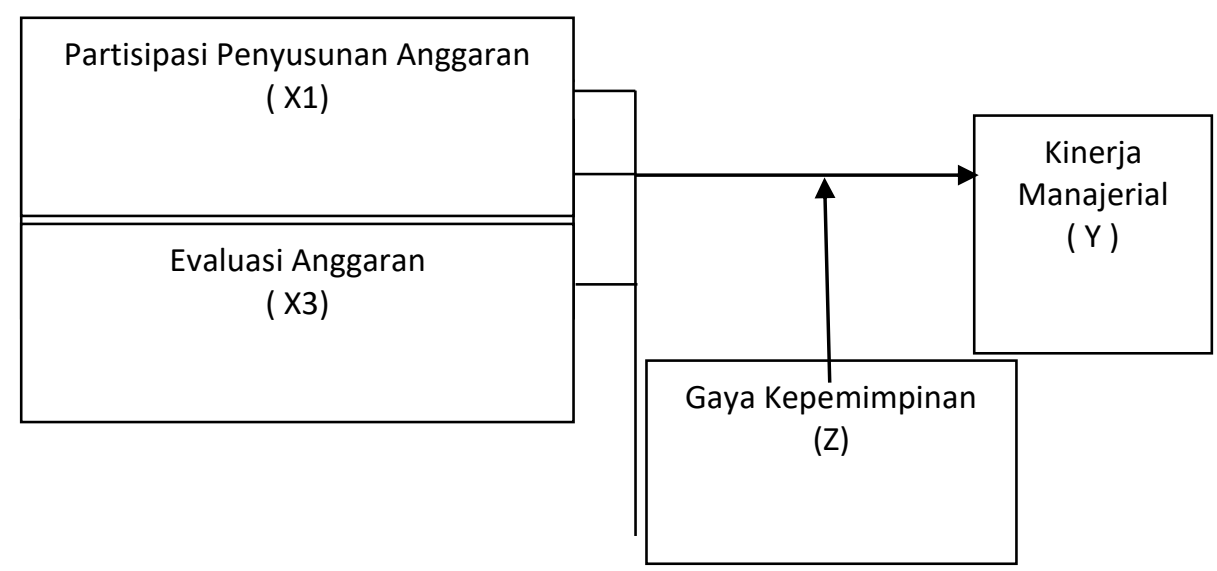

Gambar 1. Kerangka Konseptual

\section{Pengembangan Hipotesis}

Hubungan partisipasi penyusunan anggaran terhadap kinerja manajerial adalah semakin tinggi tingkat dalam penyusunan anggaran, semakin tinggi tingkat kinerja manajerial. Seperti adanya keterlibatan manajer pusat dalam pertanggung jawaban mulai dari tingkat bawah, menengah dan tingkat atas dalam proses penyusunan anggaran. Dimana keterlibatan mereka sangat penting dalam upaya memotivasi supaya mereka mencapai suatu tujuan perusahaan. Partisipasi juga merupakan suatu proses dimana individu-individu terlihat lansung didalamnya dan mempunyai pengaruh pada penyusunan anggaran, menciptakan terjadinya komunikasi yang baik, serta interaksi satu dengan yang lain. Partisipasi penyusunan anggaran dianggap juga sebagai sarana akuntansi yang terbaik untuk para pekerja dalam rangka meningkatkan diri mereka masing-masing dan dalam tanggung jawab atau tugas yang diemban. Dengan demikian anggaran yang dianggap aktualisasi dapat meningkat dengan baik dan dapat memberi pengaruh baik terhadap kinerja manajerial. 
Hubungan budaya organisasi terhadap kinerja manajerial adalah semakin tinggi tingkat kesesuaian antara partisipasi penyusunan anggaran dan budaya organisasi pada orang, semakin tinggi kinerja manajerial. Sebaliknya semakin rendah tingkat kesesuaian antara partisipasi penyusunan anggaran dan budaya organisasi pada pekerja, semakin rendah kinerja manajerial. Setiap organisasi sebenarnya memiliki budaya, memang pada umumnya orangorang dalam sebuah organisasi mudah menyetujui bahwa organisasi mereka memiliki budaya dan budaya itu sangat penting. Tetapi biasanya mereka akan menghadapi kesulitan kalau diminta untuk memberikan definisi budaya organisasi itu. Secara umum, setiap individu dilatarbelakangi oleh budaya yang mempengaruhi perilaku mereka. Budaya menuntut individu untuk berperilaku dan memberi petunjuk mengenai apa saja yang harus diikuti dan dipelajari. Kondisi tersebut juga berlaku dalam organisasi tentang bagaimana pegawai berperilaku dan apa seharusnya yang harus dilakukan. Definisi tersebut menggambarkan bahwa budaya organisasi sesungguhnya tumbuh karena diciptakan dan dikembangkan oleh individu yang bekerja dalam suatu organisasi, dan diterima sebagai nilai-nilai yang harus dipertahankan dan diturunkan kepada setiap anggota baru.

Nilai-nilai tersebut digunakan sebagai pedoman bagi setiap anggota selama mereka berada dalam lingkungan organisasi tersebut, dan dapat dianggap sebagai ciri khas yang membedakan sebuah organisasi dengan organisasi lainnya. Hubungan evaluasi anggaran terhadap kinerja manajerial adalah semakin tinggi tingkat mengevaluasi kinerja perusahaan, semakin tinggi pula kinerja manajerial. Yaitu menunjuk pada luasnya perbedaan anggaran yang digunakan kembali oleh individu pimpinan dan digunakan dalam evaluasi kinerja aparat. Model dalam anggaran tersebut digunakan dalam mengevaluasi kinerja sehingga akan berpengaruh terhadap perilaku dan kinerja dari pihak yang berpartisipasi. Perusahaan dituntut untuk meningkatkan kinerja perusahaan pada umumnya dan kinerja para manajer departemen, untuk meningkatkan kinerjanya maka diperlukan suatu alat ukur untuk mengevaluasi kinerja para manajer departemen tersebut.

Partisipasi penyusunan anggaran sebagai keterlibatan individu yang bersifat mental dan emosional dalam situasi kelompok bagi pencapaian tujuan bersama dan berbagai tanggung jawab bersama Wirjono (2007). Secara umum, setiap individu dilatarbelakangi oleh budaya yang mempengaruhi perilaku mereka. Budaya menuntut individu untuk berperilaku dan memberi petunjuk mengenai apa saja yang harus diikuti dan dipelajari. Kondisi tersebut juga berlaku dalam organisasi tentang bagaimana pegawai berperilaku dan apa seharusnya yang harus dilakukan. Definisi tersebut menggambarkan bahwa budaya organisasi sesungguhnya tumbuh karena diciptakan dan dikembangkan oleh individu yang bekerja dalam suatu organisasi, dan diterima sebagai nilai-nilai yang harus dipertahankan dan diturunkan kepada setiap anggota baru. Nilai-nilai tersebut digunakan sebagai pedoman bagi setiap anggota selama mereka berada dalam lingkungan organisasi tersebut, dan dapat dianggap sebagai ciri khas yang membedakan sebuah organisasi dengan organisasi lainnya.

Menurut Uzer (2003), mengatakan bahwa Evaluasi adalah suatu proses yang ditempuh seseorang untuk memperoleh informasi yang berguna untuk menentukan mana dari dua hal atau lebih yang merupakan alternatif yang diinginkan, karena penentuan atau keputusan semacam ini tidak diambil secara acak, maka alternatif-alternatif itu harus diberi nilai relatif, karenanya pemberian nilai itu harus memerlukan pertimbangan yang rasional berdasarkan informasi untuk proses pengambilan keputusan.

Dari penjabaran diatas dapat ditarik hipotesis sebagai berikut:

H1: Partisipasi anggaran berpengaruh terhadap kinerja manajerial

$\mathrm{H} 2$ : Budaya organisasi berpengaruh terhadap kinerja manajerial.

H3: Evaluasi anggaran berpengaruh terhadap kinerja manajerial 
H4: Gaya Kepemimpinan dapat memoderasi partisipasi Anggaran, terhadap kinerja manajerial di Bank BTN Bandar Lampung.

H5: Gaya Kepemimpinan dapat memoderasi budaya organisasi terhadap kinerja manajerial di Bank BTN Bandar Lampung.

H6: Gaya Kepemimpinan dapat memoderasi evaluasi anggaran terhadap kinerja manajerial di Bank BTN Bandar Lampung.

H7: Gaya kepemimpinan dapat memoderasi partisipasi Anggaran, budaya organisasi, evaluasi anggaran terhadap kinerja manajerial di Bank BTN Bandar Lampung.

\section{METODOLOGI PENELITIAN}

Jenis penelitian ini adalah penelitian asosiatif yang bersifat kausal (Causal Research) yang bertujuan untuk mengidentifikasi/menguji hubungan sebab akibat antara variabel. Penelitian ini bertujuan untuk menguji hipotesis dan merupakan penelitian yang menjelaskan fenomena dalam bentuk hubungan antarvariable Erlina, (2011). Penelitian ini akan mengidentifikasi bagaimana variabel independen mempengaruhi variabel dependen, serta variabel moderating mampu memoderasi hubungan antara variabel independen dengan variabel dependen. Penelitian ini menggunakan pendekatan kuantitatif. Penelitian kuantitatif adalah suatu jenis penelitian yang pada dasarnya menggunakan pendekatan deduktif- induktif. Pendekatan kuatitatif ini berangkat dari suatu kerangka teori, gagasan para ahli, maupun pemahaman peneliti bedasarkan pengalamannya, kemudian dikembangkan menjadi permasalahanpermasalahan beserta pemecahannya yang diajukan untuk memperoleh pembenaran.

Dalam penelitian ini metode analisis data yang digunakan adalah structural equation modeling (SEM) dengan menggunakan software LISREL. Rangkaian proses pengolahan data meliputi pengujian model pengukuran (measurement model), meliputi validitas dan reliabilitas, sementara pengujian model struktural (structural model) meliputi uji signifikansi pengaruh variabel independen atau eksogen terhadap varabel dependen atau endogen.

\section{HASIL DAN PEMBAHASAN}

\section{Gambaran Obyek Penelitian}

Gambaran umum responden yang telah ditemukan oleh peneliti, yang berkaitan dengan pengolahan data dalam upaya pengujian hipotesis, dalam hal melakukan penyebaran kuesioner, hasil statistik deskriptif, pengujian hipotesis dan pembahasan, penyebaran kuesioner dilakukan oleh peneliti sejak bulan oktober 2019 sampai dengan desember 2019 dengan melakukan penyebaran kuesioner kepada responden yang ada di Bank BTN Bandar Lampung. Penelitian ini menggunakan data primer yang diperoleh dari kuesioner yang dibagikan kepada 50 responden, yang terdiri wakil kepala cabang 2, kepala cabang pembantu 3, kepala kantor kas 6, kepala seksi 7, karyawan pelaksana/karyawan biasa 32 yang ada di Bank BTN Bandar Lampung. Seluruh kuesiner dibagikan terhadap 50 responden dan kembali 50 kuesioner.

\section{Pengujian Validitas Kovergen}

Berdasarkan pengujian validitas loading faktor pada nilai loading $>0.7$ dan nilai $\mathrm{P}$ value $<0,05$, yang berarti telah memenuhi syarat validitas berdasarkan nilai loading, dengan demikian dapat diartikan indikator dapat dinyatakan valid sehingga layak digunakan dalam penelitian, sebagaimana terdapat dua kriteria untuk menilai apakah outer model (model pengukuran) memenuhi syarat validitas konvergen untuk konstruk reflektif, yaitu (1) loading harus diatas 0.7 dan $(2)$ nilai $\mathrm{p}$ signifikan $(<0,05)$. 


\section{Nilai Average Variance Extracted (AVE)}

Kriteria validitas konvergen perlu diketahui nilai Average Variance Extracted (AVE) dengan nilai AVE yang disarankan adalah di atas 0,5 (Mahfud dan Ratmono, 2013:67). Berdasarkan hasil uji Lissrel yang dilakukan dapat diketahui bahwa nilai Ave pada Penerapan Partisipasi Penyusunan Anggaran 0.7591 Budaya Organisasi 0.7273, Evaluasi Anggaran 0.7918, Kinerja Manajerial 0.7594, Gaya Kepemimpinan 0.6362. sehingga dapat dikatakan indikator dalam penelitian telah memenuhi validitas konvergen.

\section{Hasil Uji Reliability}

Pengukuran reliabilitas suatu konstruk dengan indikator reflektif pada penelitian ini dilakukan dengan compositereliability untuk menilai relibialitas konstruk yakni nilai composite reliability harus lebih besar dari 0,7 (Ghozali dan Latan 2015). Berdasarkan uji Reabilitas yang dilakukan dapat diketahui bahwa nilai Composite Reliability pada masingmasing konstruk dengan penerapan Partisipasi Penyusunan Anggaran 0,9617, Budaya Organisasi 0,9696, Evaluasi Anggaran 0,9743, Kinerja Manajerial 0,9742, Gaya Kepemimpinan 0,8739, sehingga dapat dinyatakan bahwa indikator yang digunakan dalam penelitian ini telah memenuhi reliabilitas yang baik (reliable).

\section{Uji Hipotesis}

Tabel 2 Hasil uji hipotesis

\begin{tabular}{lccc}
\hline Pengaruh & Koefisien jalur (Path Coefficient) & P. Value & R.Square \\
\hline PPA (X1) -> KM (Y) & 025 & 2,04 & \\
\cline { 1 - 3 } BO (X2) -> KM (Y) & 0,30 & 2,05 \\
\cline { 1 - 3 } EA (X3) -> KM (Y) & 0,33 & 2,29 \\
\hline
\end{tabular}

Berdasarkan hasil pengujian hipotesis menunjukkan bahwa variabel partisipasi penyusunan anggaran bernilai positif yang berarti menunjukkan hubungan antara partisipasi penyusunan anggaran searah dengan kinerja manajerial. Pengaruh penerapan partisipasi penyusunan anggaran terhadap kinerja manajerial menunjukkan bahwa persepsi responden setuju dengan adanya penerapan partisipasi penyusunan anggaran pada Bank BTN Bandar Lampung, maka akan meningkatkan terwujudnya kinerja manajerial yang mampu mempertanggungjawabkan akan anggaran demi kemajuan Bank tersebut. Laporan keuangan sebagai pertanggungjawaban manajer akan akuntabel jika memenuhi semua prinsip partisipasi penyusunan anggaran. Bank BTN Bandar Lampung yang telah menerapkan partisipasi penyusunan anggaran maka realisasi anggaran akan lebih akuntabel. Pada Bank BTN Bandar Lampung yang menerapkan prinsip partisipasi penyusunan anggaran dengan adanya transparansi oleh Bank BTN Bandar Lampung atas adanya anggaran dengan membuat laporan keuangan yang jelas disetiap tahun nya, hal ini dilakukan dalam mewujudkan transparansi Bank BTN Bandar Lampung, dimana posisi Bank BTN sendiri sebagai bank pemerintah atau BUMN, dalam hal ini tidak bisa lepas dari regulasi. Sehingga dengan demikian berbagai kegiatan Bank BTN Bandar Lampung lebih jelas. Penggunaan keuangan yang merupakan wewenang dari pada manajer harus dapat digunakan secara efektif dan efisien, hal ini merupakan sebagai wujud dari penerapan kinerja manajerial yang baik. . Hasil penelitian ini juga sejalan dengan penelitian sebelumnya yang dilakukan Aznuriyandi (2010), yang menyatakan partisipasi anggaran berpengaruh signifikan terhadap kinerja manajerial.

Berdasarkan hasil pengujian hipotesis menunjukkan bahwa variabel budaya organisasi bernilai positif yang menunjukkan hubungan antara budaya organisasi searah dengan kinerja 
manajerial. Pengaruh penerapan budaya organisasi terhadap kinerja manajerial menunjukkan bahwa persepsi responden setuju dengan adanya penerapan budaya organisasi pada Bank BTN Bandar Lampung, maka akan meningkatkan terwujudnya kinerja manajerial yang mampu mempertanggungjawabkan akan anggaran demi kemajuan Bank tersebut. Budaya organisasi sesungguhnya tumbuh karena diciptakan dan dikembangkan oleh individu yang bekerja dalam suatu organisasi, dan diterima sebagai nilai-nilai yang harus dipertahankan dan diturunkan kepada setiap anggota baru. Hasil penelitian ini juga sejalan dengan penelitian yang dilakukan Irianto (2014) yang menyatakan budaya organisasi berpengaruh signifikan terhadap kinerja manajerial.

Berdasarkan hasil pengujian hipotesis menunjukkan bahwa variabel evaluasi anggaran bernilai positif yang berarti menunjukkan hubungan antara evaluasi anggaran searah dengan kinerja manajerial. Perusahaan dituntut untuk meningkatkan kinerja pada umumnya dan kinerja para manajer departemen, untuk meningkatkan kinerjanya maka diperlukan suatu alat ukur untuk mengevaluasi kinerja para manajer dapartemen tersebut. Pengaruh penerapan evaluasi anggaran terhadap kinerja manajerial menunjukkan bahwa persepsi responden setuju dengan adanya penerapan evaluasi anggaran pada Bank BTN Bandar Lampung, maka akan meningkatkan terwujudnya kinerja manajerial yang mampu mempertanggungjawabkan akan anggaran demi kemajuan Bank tersebut Pada Bank BTN Bandar Lampung yang menerapkan tujuan evaluasi anggaran dengan adanya transparansi oleh Bank BTN Bandar Lampung atas adanya anggaran dengan membuat laporan keuangan yang jelas disetiap tahun nya, hal ini dilakukan dalam mewujudkan transparansi Bank BTN Bandar Lampung,Semakin tinggi evaluasi anggaran maka kinerja manajerial akan semakin tinggi. Evaluasi adalah suatu proses yang ditempuh seseorang untuk memperoleh informasi yang berguna untuk menentukan mana dari dua hal atau lebih yang merupakan alternatif yang diinginkan, karena penentuan atau keputusan semacam ini tidak diambil secara acak, maka alternatif-alternatif itu harus diberi nilai relatif, karenanya pemberian nilai itu harus memerlukan pertimbangan yang rasional berdasarkan informasi untuk proses pengambilan keputusan. Hasil penelitian ini juga sejalan dengan penelitian yang dilakukan rizki dan salbiyah (2012) yang menyatakan evaluasi anggaran berpengaruh signifikan terhadap kinerja manajerial.

Berdasarkan hasil pengujian moderasi Partisipasi Penyusunan Anggaran, Budaya Organisasi, Evaluasi Anggaran dengan Gaya Kepemimpinan sebagai variabel moderating secara bersama-sama tidak berpengaruh terhadap kinerja manajerial maka disimpulkan seorang manajer tidak memiliki pengaruh dalam proses penganggaran dan dalam penilaian kinerja manajerial. Dalam artian apapun itu gaya kepemimpinan seorang manajer atas tidaklah mempengaruhi kinerja dalam proses partisipasi penyusunan anggaran. Hasil ini sejalan dengan penelitian yang dilakukan oleh Yuniarti (2008) dan Nor (2007) yang menyatakan bahwa Partisipasi Penyusunan Anggaran, Budaya Organisasi, Evaluasi Anggaran dengan Gaya Kepemimpinan tidak berpengaruh terhadap KinerjaManajerial Pada hasil analisis koefisien determinasi dilakukan dengan melihat total R-Square pada variabel dependen dalam model sehingga dapat dilihat sejauh mana variabel dependen tersebut. Nilai R-Square dari Lisrel berdasarkan hasil output yang dihasilkan dengan memperoleh nilai R-Square pada model sebesar 0.571, artinya Partisipasi penyusunan anggaran, budaya organisasi, evaluasi anggaran mampu mempengaruhi kinerja manajerial sebesar $57,1 \%$. Sisanya sebesar $42,9 \%$ dipengaruhi oleh faktor-faktor yang lain. Gaya kepemimpinan tidak signifikan dalam memoderasi pengaruh partisipasi penyusunan anggaran, budaya organisasi, dan evaluasi anggaran terhadap kinerja manajerial. 


\section{KESIMPULAN DAN SARAN}

\section{Kesimpulan}

Berdasarkan hasil penelitian dan pembahasan, maka kesimpulan dalam penelitian ini, pengaruh partisipasi penyusuanan anggaran, budaya organisasi, dan evaluasi anggaran penerapan berpengaruh positif dan signifikan dan Gaya kepemimpinan tidak signifikan dalam memoderasi pengaruh partisipasi penyusunan anggaran, , budaya organisasi, dan evaluasi anggaran terhadap kinerja manajerial.

\section{Saran}

Dari hasil penelitian ini terlihat bahwa, partisipasi penyusunan anggaran berpengaruh terhadap kinerja manjerial. Oleh karena itu ada baiknya Bank BTN Kantor Cabang Bandar Lampung memperhatikan, memperbaiki dan menerapkan komitmen organisasi yang dapat mengarahkan pegawai untuk bekerja lebih baik. Untuk penelitian selanjutnya yang menggunakan judul yang sama, sebaiknya dilengkapi dengan wawancara, dan penggantian teknik pengambilan sampel penelitian, serta dilakukan perubahan dalam pemilihan alternatif jawaban pada kuesioner sehingga dapat menggali semua hal yang menjadi tujuan penelitian. Untuk penelitan selanjutnya, dikarenakan adanya variabel lain yang mempengaruhi kinerja instansi pemerintah daerah, maka hendaknya peneliti selanjutnya menambahkan atau mengganti variabel yang diteliti dengan variabel lain, seperti informasi asimetri, kepuasan kerja.

\section{DAFTAR PUSTAKA}

Erlina, 2011. Metodologi PenelitianBisnis, Usu Press, Medan.

Garrison, Ray H. dan Eric W. Noreen, 2000. Akuntansi Manajemen, Salemba Empat, Jakarta.

Ghozali, Imam. 2006. Aplikasi Analisis Multivariate dengan Program SPSS (Edisi Ke 4). Semarang: Badan Penerbit Universitas Diponegoro.

Irianto, O. (2000). Pengaruh Partisipasi Penyusunan Anggaran, Budaya Organisasi dan Locus of Control Terhadap Kinerja Manajerial pada SKPD Kabupaten Merauke. Journal of Universitas Mesamus Merauke, 301(5), 1163-1178.

Salbiah., Rizky, R. (2012). Pengaruh Evaluasi Anggaran Terhadap Kinerja Satuan Kerja Perangkat Daerah (SKPD) Pemerintah Provinsi Sumatera Utara. Jurnal Ekonom, 15 (2), 42, 42-52.

Uzer 1993. Upaya Optimalisasi Kegiatan Belajar Mengajar. Bandung: Remaja Rosdakarya. Wirjoo, E. R dan A. B Raharjo. 2007. Pengaruh Karakteristik Personalitas Manajemen Terhadap Hubungan Antara Partisipasi dalam Penyusunan Anggaran dengan Kinerja Manajerial. Jurnal Kinerja. Vol. 11 (1): 50-63. 